\author{
Marta Kowalczyk-Ludzia
}

\title{
Closing Speech - Between Theory and Practice
}

\author{
Thus, is one is ashamed to say what they think, \\ they must say things that contradict one another. \\ Plato, Gorgias
}

The development of the art of speaking is an integral element of each trial. According to the code, after closing the judicial proceedings the parties take the floor in a predetermined order: the public prosecutor, the subsidiary prosecutor, the private prosecutor, the defence attorney and the defendant. Representatives of parties in the trial speak before the parties (Article 406 of the Polish Code of Criminal Procedure) ${ }^{1}$. Such an arrangement enables the stakeholders to express their position in the case concerned and present to the court their own interpretation of the events. Also, "when it is time for the parties to speak, they may discuss the results of the evidentiary hearing and show any gaps, irregularities or failures in it." ${ }^{2}$ The above order is not random, but rather, looking at it from the perspective of the rights of the defendant, it is an important aspect of the execution of the right of defence.

It is worth mentioning here the praxeological nature of the above provision. Article 406 PCC is supposed to give a chance to both active and passive parties to the proceed-

1 The full article 406 of the Polish Code of Criminal Procedure reads as follows: Article $406 \S 1$. After completion of the taking of evidence, the presiding .e shall call upon the parties, their representatives, and, if necessary, on the social representatives, who shall speak before the defence counsel and the accused, to present their oral arguments. The parties shall speak in the following order: public prosecutor, subsidiary prosecutor, private prosecutor, civil plaintiff, defence counsel, and the accused. The representatives of the parties for the trial shall speak before the parties.. Polish Act of 6 June 1997 - Code of Criminal Procedure - Dz.U.1997, no. 89, item 555 , as amended.

2 J. Bafia, J. Bednarzak, M. Flemming, S. Kalinowski, H. Kempisty, M. Siewierski, Kodeks postępowaniakarnego.Komentarz,ed.M.Mazur,Wydawnictwo Prawnicze,Warszawa1971,p.419. 
ings to accentuate both positive and negative aspects of the verification of the defendant's criminal conduct. Also, $§ 2$ of the above provision states that: "If the prosecutor takes the floor again, the defence attorney and the defendant should also be allowed to speak." ${ }^{3}$ Thus, the provision supports the principle of the equal rights of parties. ${ }^{4}$

Thus, it could be generalised that "the purpose of speeches is to present to the court the position of parties, helping to shape an objective view of the case. At the same time, they are also contradictory". ${ }^{5}$

The speeches of defence attorneys should be particularly helpful for the defendant, for whom the above provision gives the last chance to emphasise attenuating circumstances that may affect the punishment, or highlight the reasons why the defendant should be acquitted. Moreover, the closing speech should summarise the results of the proceedings. According to the principle of objectivity (Article 4 of the Polish Code of Criminal Procedure), notwithstanding the position presented in a given case, the final speech should contain arguments both in favour and to the prejudice of the accused. Thus, it is rightly emphasised in the literature on the subject that "the first duty of a speaker, in order to achieve internal balance, is to develop an objective opinion about people and problems. The consequence of such a position is tolerance of opinions different from our own." ${ }^{\circ}$

The court, when determining the punishment, should also make sure to execute the function of the criminal law, in particular the function of rightfulness. ${ }^{7}$

Thus, taking into consideration the arguments of the opposing party, the effectiveness of the final speech is worth analysing. Closing speeches should not be associated with complicated paeans that depart from the core of the case concerned.

3 Polish Act of 6 June 1997 - Code of Criminal Procedure - Dz.U. 1997, no. 89, item 555, as amended.

4 For more information, vid.: T. Grzegorczyk, J. Tylman, Polskie postępowanie karne, Wydawnictwo LexisNexis, Warszawa 2000, pp. 121-122. M. Cieślak, Polska procedura karna: podstawowe zatożenia teoretyczna, Państwowe Wydawnictwo Naukowe, Warszawa 1971, pp. 264 et seq.

5 M. Lipczyńska, R. Ponikowski, Maty komentarz do kodeksu postęporwania karnego, Państwowe Wydawnictwo Naukowe, Warszawa 1988, p. 265. It is also postulated that the provision contained in Article $406 \S 1$ of the Polish Code of Criminal Procedure "is associated with the party's right to highlight irregularities or gaps in the evidentiary hearing or challenge the assumed facts by claiming that additional evidence is needed or the judicial proceedings need to be repeated, as well as the right to discuss the guilt and punishment, and the purposefulness of coercive measures." - W. Cieślak, K. J. Pawelec, I. Tuleya, Kodeks postępowania karnego. Praktyczny komentarz do zmian, Wydawnictwo Difin, Warszawa 2015, p. 310, quotation after the Judgement of the Supreme Court of 18 January 1980, III KR 421/79, Lex no. 17210.

6 T. Gout, Sztuka wymowy. Technika publicznego przemawiania - częśc I, Spółdzielnia Wydawnicza „Nowa Epoka”, Warszawa 1946, p. 58.

7 The rightfulness function is associated with "satisfying the sense of justness of the person affected by a crime, as well as the victim's family and social group, by punishing the perpetrator." - L. Gardocki, Prawo karne, Wydawnictwo C. H. Beck, Warszawa 2015, p. 7. 
Considering the above, the following research question was formulated: when is a closing speech indeed effective, and at the same time meeting its theoretical and practical assumptions?

The following hypothesis is posited: the recapitulation of the positions of the parties to proceedings is not sufficiently used as a defence (or, respectively, prosecution) tool, and in particular is underestimated by law practitioners.

In order to verify the assumptions presented above, 200 court files were examined. The research was conducted in 2015 at the District Court in Olsztyn and the Regional Court in Olsztyn. All the examined cases concluded with a convicting judgment and took place in 2012 and 2013. In terms of the methodology of the research, the author has decided to present a few conclusions from the file examination, because "the examined files very closely reflect the practice and make it possible to formulate a number of scientific conclusions." ${ }^{8}$ Only selected results of the examination are presented in this paper, given its limited size, which makes it impossible to present them in more detail. The results of the examination of court files may be summarised in the following way:

\section{The Purpose of an Effective Closing Speech Should be a Sincere Recapitulation of Proceedings}

Meanwhile, in many cases the defendants intentionally tried in closing speeches to shift responsibility for the crime to other persons. Promoting an "elusive defence" ${ }^{9}$, which, although it is not legally prohibited, is highly unethical and does not correspond to the idea of diligent conduct. Reducing one's role in a crime by shifting penal responsibility to other persons does not contribute to the proper execution of the right of defence and may even - according to the case law of the Supreme Court - result in more severe punishment ${ }^{10}$. An example of this is a situation where a person accused of a crime under Article 207 \$ 1 CC claimed that: "my wife was angry at me for being drunk. She attacked me and I defended myself, or maybe it was the other way round. It just happened." 11 This admissible - but not entirely ethical - example of the execution of the right of defence

8 J. Kasprzak, Wybrane problemy metodologiczne badań w zakresie procesu karnego i kryminalistyki, in: Wybrane problemy procesu karnego i kryminalistyki, eds. J. Kasprzak, B. Młodziejowski, Wydawnictwo Volumina.pl Daniel Krzanowski, Szczecin-Olsztyn 2010, p. 13.

9 Defence becomes elusive when it reveals low moral level or the defendant's ill will, and then it may become an aggravating circumstance. H. Kempisty, Metodyka pracy sędziego w sprawach karnych, Wydawnictwo Prawnicze, Warszawa 1955, p. 254.

10 See Resolution of the Supreme Court of 11 January 2006 , I KZP 49/05, OSNKW 2006, no. 2, item.12. See also:Judgement of the Court of Appeal in Katowice of 29 March 2001, II Aka 98/01.

11 Judgement of the District Court in Olsztyn, file no. II K 469/12. 
is defined in judicial psychology as "protective motives". ${ }^{12}$ Józef Krzysztof Gierowski explains such behaviour in the following way: "Psychological research into crime motives should take into account not only the possibility that the perpetrator will intentionally conceal or distort the motives of his conduct due to fear of punishment, but also that many, often unconscious, protective mechanisms will be triggered". ${ }^{13}$ Such behaviour of defendants, although understandable, as it is supposed to help achieve a favourable verdict, should not be approved, especially by lawyers taking part in the proceedings.

\section{An Effective Final Speech Should Indicate Whether the Educational Aspects of the Proposed Sentence are Going to be Achieved}

Considering Article 53 of the Polish Criminal Code, according to which: "The court passes a sentence at its own discretion, within the limits prescribed by law, ensuring that the severity does not exceed the degree of guilt, being aware of the degree of social consequences of the act, and taking into account the preventive and educational objectives that the penalty is to achieve with regard to the offender, as well as the need to develop legal awareness in society" ${ }^{14}$, the parties should in their closing speeches accentuate those aspects, especially that they are not indifferent to the judgement. The statements need not be elaborate sometimes a simple sentence is sufficient, such as, for example, the following: "I didn't want to do it, but it happened."15, or: "I would like to apologise to the family and perhaps my imprisonment will at least partly compensate the harm done to them. I would like to apologise to the victim's mother." ${ }^{\text {, }}$, or: "I would like to say sorry to everyone and ask for a light punishment." ${ }^{17}$

As the court practice shows, such statements should each time be treated very carefully, because, as is rightly observed in the literature on the subject, such "[...] admission of guilt may be the effect of cold calculation associated with the possibility of achieving certain advantages, e.g. extraordinary mitigation of punishment." ${ }^{18}$ On the other hand, admission of guilt and repentance may not be a proof worthy of discrediting. It is rightly observed that: "admission of guilt requires overcoming certain psychological barriers.

12 J. K. Gierowski, T. Jaśkiewicz-Obydzińska, M. Najda, Psychologia w postępowaniu karnym, Wydawnictwo LexisNexis, Warszawa 2008, p. 342.

13 Ibidem, p. 342.

14 Polish Act of 6 June 1997 - Criminal Code -Dz.U. 1997, no. 88, item 553, as amended.

15 The Judgement of the Regional Court in Olsztyn - II K 181/13.

16 The Judgement of the Regional Court in Olsztyn - II K 149/12.

17 The Judgement of the Regional Court in Olsztyn - II K 156/13.

18 Z. Muras, Wyjaśnienia oskarżonego w procesie karnym i prawie karnym materialnym, Wydawnictwo C. H. Beck, Warszawa 2005, p. 91, quotation after: K. J. Pawelec, Wyjaśnienia oskarżonego, p. 26, and Z. Rau, Przestępczość zorganizowana w Polsce i jej zwalczanie, Kraków 2002, p. 215. 
It can play an important educational role. It is also often associated with self-criticism and deep analysis of one's behaviour. Sometimes it is also a milestone in the life of a criminal, who experiences true repentance and willingness to return to society." ${ }^{19}$ This issue is also interestingly discussed by Henryk Kempisty, who observes that: "If a defendant really shows repentance in an indisputable way, sometimes admission of guilt may be recognised as a mitigating circumstance. ${ }^{20}$ Nonetheless, such statements in the closing speech of the defendant, although they require consideration, can be an important moral element for the defendant, which is not irrelevant to the educational aspect of proceedings.

\section{An Effective Closing Speech Requires a More Professional Involvement in its Preparation and Delivery}

The defence attorney's speech is an integral element of the execution of the right of defence (Article 6 of the Polish Code of Criminal Procedure). Undoubtedly, "not hearing the defence attorney after closing the judicial proceedings is an oversight that may affect the sentence, as it deprives the defendant of the attorney's help immediately prior to the issuing of the judgement." 21

It is also evident that the defence attorney should also act to the advantage of the defendant. ${ }^{22}$ A predictable implication of this assumption is usually a contradiction of the prosecutor's position. Taking into account the dynamics of efforts to achieve the desired results, the arguments used in the closing speech should be well informed. However, it should be noted here that the rhetoric of the defence speech should not go beyond the ethical limits of eristic. ${ }^{23}$ Dishonest eristic tricks are contrary to legal ethics and the standards of diligent criminal process. ${ }^{24}$ Moreover, considering the objectives of the criminal

19 Ibidem, p. 91.

20 H. Kempisty, Metodyka pracy sędziego w sprawach karnych, Wydawnictwo Prawnicze, Warszawa 1955, p. 254.

21 J. Bafia, J. Bednarzak, M. Flemming, S. Kalinowski, H. Kempisty, M. Siewierski, Kodeks postępowania karnego. Komentarz, ed. M. Mazur, Wydawnictwo Prawnicze, Warszawa 1971, p. 421.

22 It is rightly claimed by Stanisław Śliwiński that "first of all, every action of the defence attorney to be to the advantage of the defendant, wilfully taken by the attorney, contains a substitution element that directly affects the defendant's position in proceedings." - S. Śliwiński, Polski proces karny przed sqadem powszechnym. Zasady ogólne, Państwowe Wydawnictwo Naukowe, Warszawa 1959, p. 203.

23 Cf. Dowody i postępowanie dowodowe w procesie karnym. Komentarz praktyczny z orzecznictwem. Wzory pism procesowych, ed. P. Kruszyński, M. Błoński, M. Zbrojewska, , Wydawnictwo C. H. Beck, Warszawa 2015, p. 27.

24 For example, one of these tricks is to distort the opponent's thesis in such a way that it seems that the same thesis is simply repeated. Obviously, especially in more complicated cases, it is 
process (Article $2 \S 1$ of the Polish Code of Criminal Proceedings) and the principle of material truth (Article $2 \S 2$ of the Polish Code of Criminal Proceedings), the closing speech should be a diligent execution of the right to defence (Article 6 of the Polish Code of Criminal Proceedings).

Meanwhile, in practice, the position of the defence attorney is many times limited to the following statement: "I petition as is stated in the pleading and for a decision as to the costs of defence." ${ }^{25}$. Such a statement has little to do with the execution of the right of defence in the broad meaning of the term. It should be noted that the defence attorney, being an experienced professional and not engaged emotionally in a case, should not only suggest the desired outcome of the proceedings in his closing speech, but it is also his duty to help the defendant to highlight the alleviating circumstances of his behaviour. A relevant example is the case reviewed in 2012 at the Regional Court in Olsztyn concerning an accusation of serious damage to health (Article $156 \S 3$ CC) and murder (Article 148 $\S 1 \mathrm{CC}$ ). Upon completion of judicial proceedings, the defence attorney, summarising the proceedings, asked to change the legal qualification of the act and apply extraordinary mitigation of punishment ${ }^{26}$. Compared to the defendant's speech, the defence attorney's suggestion turned out to be quite laconic. In his last words, the defendant claimed: "I would like to say that I am very sorry and I apologise. I want to repeat that I did not intend to kill. I would like to ask for extraordinary mitigation of punishment. I would like to go back to school and have different friends, because in the penal institution I befriended morally depraved people [...] They abused me very much and made me have two tattoos done against my will. I don't want to, I'm afraid to go back there again. I survived half a year there." ${ }^{27}$

The form of the defendant's statement presented above proves how psychologically and emotionally difficult it is to participate in a criminal case. Therefore, it is justified to involve the defence counsel in formulating the final speech, which in particular emphasizes those circumstances that are favourable for the accused. The defence attorney, as a professional, could independently present the defendant's arguments to the court, but in a more orderly and coherent fashion, in terms of content and tone. ${ }^{28}$ The need to cooperate in this respect makes the right of defence even more efficient. Similar positions are presented in the

difficult to formulate sentences that are entirely unequivocal, and they only become more or less unequivocal in association with other sentences in the text. Z. Ziembiński, Logika praktyczna, Wydawnictwo Naukowe PWN, Warszawa 2002, p. 214. See also: Rzetelny proces karny w orzecznictwie sąów polskich i międzynarodowych, ed. P. Wiliński, Wydawnictwo Oficyna a Wolters Kluwer business, Warszawa 2009. See also Article 45.1 of the Constitution of the Republic of Poland of 2 April 1997 adopted by the National Assembly on 2 April 1997 - Dz.U. 1997 no. 78 item 483.

25 See, for example, the Judgement of the District Court in Olsztyn VII K 132/12, VII K 125/12.

26 See Judgement of the Regional Court in Olsztyn - II K 106/13.

27 See Judgement of the Regional Court in Olsztyn - II K 106/13.

28 Cf. S. Jaworski, Metodyka pracy adwokata i radcy prawnego w sprawach karnych, Wydawnictwo C. H. Beck, Warszawa 2015, pp. 194-198. 
literature on the subject and in the case law, as "[...] the complementarity of the efforts of the defence attorney and his client is noticeable. The speech of a defence attorney who has professional knowledge supports the defence with strictly legal arguments the lack of which is not compensated for by the usually emotional speech of the defendant." ${ }^{29}$

Another thing needs emphasising here, namely in the closing speech the effectiveness of defence is not synonymous with asking for acquittal if the defendant's guilt has been proven beyond any doubt. According to Stanisław Śliwiński, “The defendant does not have to always contradict everything; if he did, he would ridicule himself many times. On the contrary, he should properly evaluate and illuminate facts and use them as best as is possible in the interest of the defendant." ${ }^{30}$ A practical example of these deliberations is the reasonable position of the defence attorney who claimed that "he petitions that the defendant be considered guilty of the accusation, but that he should be punished in a just way and in consideration of all the relevant circumstances." ${ }^{31}$

One more thing should be noted here: an informed, succinct and orderly speech promotes legal culture in society. As is interestingly suggested by Mieczysław Szerer: "it is the duty of the defence attorney to highlight all the weaknesses in the prosecutor's reasoning, as it is not only in the interest of the defendant, but also in the interest of society that the indictment is free of any factual and legal gaps. Even if the failures are minor and the court will most likely notice them, it is not indifferent to the public interest if they are left uncorrected." ${ }^{2} 2$ Such just observation needs no comments.

\section{Effective Closing Speech for the Prosecution Requires More Professional Involvement in its Preparation and Delivery}

In the examined cases the speech of the public prosecution is usually expressed in the following statement: "The prosecutor petitions that the defendant be considered guilty and that a punishment be determined for him"33 - after which, depending on the type and gravity of the act, the prosecutor suggests a punishment that is appropriate in his opinion. ${ }^{34}$ This sug-

29 P. K. Sowiński, Ostatnie stowo oskarżonego (art. 406 k.p.k.), in: Węztowe problemy procesu karnego, ed. P. Hofmański, Warszawa 2010, p. 672, quotation ater: Judgement of the Supreme Court of 9 August 2002, V KKN380/00, LEX no. 57167.

30 S. Śliwiński, Polski proces karny przed sqadem powszechnym. Zasady ogólne, Państwowe Wydawnictwo Naukowe, Warszawa 1959, p. 204.

31 The judgement of the Regional Court in Olsztyn - II K 181/13.

32 M. Szerer, Kultura i Prawo, Państwowy Instytut Wydawniczy, Warszawa 1981, p. 177.

33 See, for example, Judgement of the District Court in Olsztyn VII K 109/12, VII K 144/12, VII K 145/12, VII K 125/12, VII K 88/12, VII K 95/12, VII K 96/12, VII K 107/12, VII K 85/12, VII K 82/12, Regional Court in Olsztyn II K 106/13.

34 See, for example, Judgement of the District Court in Olsztyn: VII K 82/12. 
gestion is important - it enables the prosecutor to present his or her position after the judicial proceedings are closed. Nonetheless its substantiation within the framework of the "voices of the parties" should be properly supported, even though the same arguments were already expressed in the indictment. All the more so since "the prosecutor's demand for specific penalties has been questioned in literature and supported by the argument that such a practice affects the intensification of judicial punitive repression and the discrepancies between the extent of the sentence given by the court and the prosecutor's demand cause confusion among the public and create a myth that courts are excessively indulgent towards criminals." ${ }^{35}$

In view of the rationale behind the defendant's demands set out in the indictment, the prosecutor should adequately substantiate his or her position. Additionally, proper exercise of the "rights of defence" in accordance with art. $406 \S 1$ of the Code of Criminal Procedure - the defendants right to have his last word (the favor defensionis principle) - requires the claimant and his defence counsel examine the defendant's views on the assessment of the offence committed even after the court proceedings have been concluded. In view of the situations in which the thesis of the indictment becomes obsolete after all the circumstances of the case have been clarified at the trial, the prosecutor should therefore, in his or her final speech, refer to the findings currently reached and not passively cite the arguments contained in the act of indictment (especially when the relevant circumstances of the case have been presented differently from those established in the pre-trial proceedings). ${ }^{36}$

If the speech for the prosecution emphasised both evidence for and mitigating circumstances concerning the crime, it would offer an even more explicit evaluation of the crime, while at the same time being objective (Article 4 of the Polish Code of Criminal Procedure).

\section{The Final Speech Should be Consistent with the Principle of Favor Defensionis}

In many of the examined cases the closing speech boiled down to the same sentence: "it is petitioned as is stated in the initial petition." ${ }^{37}$ This laconic statement is often repeated after the prosecutor or defence attorney by defendants themselves. Such a position, al-

35 R. A. Stefański, Metodyka pracy prokuratora w sprawach karnych, Wydawnictwo Wolters Kluwer, Warszawa 2017, p. 619, cited from: J. R. Kubiak, Wnioski prokuratora w przedmiocie wymiaru kary a sędziowski wymiar kary, Zeszyty Naukowe Instytutu Badania Prawa Sądowego 1979, no. 12; idem, Wnioski prokuratora co do wymiaru kary (uwagi krytyczne), Palestra 1980, no. 1; idem, W sprawie wniosków prokuratora co do wymiaru kary, Palestra 1982, no. 1-3.

36 Cf. A. Seremet, Odpowiedzialność prokuratora za niestuszne skazanie, in: Niestuszne skazaniaprzyczyny i skutki, ed. Ł. Chojniak, , Wydawnictwo C. H. Beck, Warszawa 2017, p. 67.

37 See, for example the Judgement of the District Court in Olsztyn VII K 109/12, VII K 88/12, VII K 95/12, VII K 96/12, VII K 85/12, VII K 82/12, VII K 132/12. 
though it is probably meaningful for the representatives of judicial authorities, may at the same time suggest that the defendant is too stressed to exercise his right to defence. The manifestation of this principle is, among others, the actual exercise of the defendant's right to the last word (the favour defensionis principle). Therefore, it is highlighted that "it is unacceptable to limit the defendant's statement only to answering the questions whether he or she upholds the arguments of his or her defence counsel and follows the same motions", "what motions the defendant has", "what sentence he or she expects" or "what extent of punishment he or she expects". The jurisprudence rightly states that failure to grant the defendant the right to speak and thus prevent him or her from presenting his or her own procedural reasons, including reference to the proceedings and the evidence gathered, and to prevent him or her from responding to the opinion of the prosecutor [...] should result in the sentence being revoked." 38 It should therefore be emphasised that, despite the fact that the summary of proceedings "[...] is a difficult activity, resembling a kind of a game from which every participant wants to emerge, in his or her opinion, as a winner." ${ }^{39}$, the termination and appropriate justification of one's position contributes to the full understanding of the party's views. Although it is usually a major effort for the defendant to formulate his or her final speech - it is important to remember that he or she should be able to fully exercise his or her entitlement - so that the final speech is concise but not too laconic.

\section{The Closing Speech Should Answer the Question About the Real Cause of the Prohibited Act Committed}

This way revealing the true motivation of the defendant when committing the crime. A good example here is a case reviewed by the District Court concerning a crime under Article 286 § of the Polish Criminal Code. In his final words the defendant "petitioned for a severe punishment so that he would have food provided for him." ${ }^{40}$ Only the defendant's true position will enable the court to issue a right and just verdict, so the credibility of the defendant's "last words" is very important. ${ }^{41}$

38 Kodeks postępowania karnego. Komentarz, ed. J. Skorupka, Wydawnictwo C. H. Beck, Warszawa 2016, p. 1028.

39 E. Gruza, Psychologia sqqdowa dla prawników, Wydawnictwo Oficyna a Wolters Kluwer business, Warszawa 2009, p. 112.

40 Judgement of the District Court in Olsztyn VII K 107/12.

41 See the Judgement of the Supreme Court of 23 July 1975, II KR 62/75, OSNKW 1975, no. 9, item 126. 


\section{Conclusions}

Ensuring an adequate standard of criminal proceedings meets constitutional ${ }^{42}$ and international ${ }^{43}$ requirements. Taking into consideration this standard, we should not overlook the necessity of shaping the efficiency of final speeches, especially as it is applied in the implementation of such principles as the favor defensionis principle or the audiatur et altera pars rules mentioned in the study. Moreover, it should be stressed that procedural deficiencies in this respect may constitute an important argument concerning the violation of the rights to defence (Article 6 of the Polish Code of Criminal Procedure). Deficiencies in the implementation of this principle constitute a denial of not only statutory guarantees (Article 6 of the Polish Code of Criminal Procedure) but also constitutional ones (Article 42 (2) of the Constitution of the Republic of Poland). If, therefore, it is accepted that "the rights of defence include any action taken in the interests of the defendant which seeks to repel the accusation [...] or to reduce his liability in an appropriate manner and to reduce any procedural inconvenience" ${ }^{44}$, then the scope of such actions include the properly exercised right to effective final speech that will contribute to a fair outcome.

Considering the above, it should be concluded that first of all, the importance of rhetoric in criminal proceedings is hard to dispute. Secondly, unfortunately, the aspects associated with the implementation of the provisions of Article 406 of the Polish Code of Criminal Procedure are not sufficiently acknowledged and used by practitioners and others, as is shown by the above examples. Meanwhile, the recapitulation of the proceedings and the presentation of one's position in the case concerned may effectively contribute to achieving (at least partly) ones' objectives. It is worth "[...] considering what opinion about facts the court can have after closing the evidentiary hearing. The court may have the same convictions as the speaker - then they expect arguments that would confirm their own judgement, but they can also be uncertain or have a completely different opinion - then some kind of surprising arguments that they did not take into consideration would be very persuasive." 45

It should also be noted that, as Piotr Krzysztof Sowiński rightly claims, "separating 'the voices of the parties' by placing them in a separate (46th) chapter of the Code of Criminal Proceedings would not only serve the purpose of the ease of reference, but would also prove the importance of this procedural activity which constitutes another

42 Article 45.1 of the Constitution of the Republic of Poland of 2 April 1997 adopted by the National Assembly on 2 April 1997 - Dz.U. 1997 no. 78 item 483.

43 See, for example Article 6.3 of the European Convention for the Protection of Human Rights and Fundamental Freedoms made in Rome on 4 November 1950, as amended by Protocols Nos. 11 and 14 and supplemented by Protocol no. 2 - OJ.1993.61.284.

44 Kodeks postępowania karnego. Komentarz, ed. J. Skorupka, Wydawnictwo C. H. Beck, Warszawa 2016, s. 28, cited from: K. Marszał, Proces karny, 2013, s. 138.

45 J. Jabłońska-Bonca, Prawnik a sztuka negocjacji i retoryki, Wydawnictwo Prawnicze LexisNexis, Warszawa 2003, p. 134. 
vital element of the main trial immediately preceding the issuance of the verdict" ${ }^{46}$ This author also convincingly claims that "superficial reporting or not reporting at all in the minutes of the trial the speeches of the parties deprives the appellate court of the possibility to comprehensively analyse the position of the court of the first instance", thus significantly hindering the review of the case." ${ }^{47}$

Oratorical competitions organised by legal circles ${ }^{48}$ are useful as they highlight the important role of rhetoric in the criminal process. Thus, if the closing speech is an integral element of the trial, then, in the author's opinion, the teaching of this skill should be more thorough, not only during practical legal training but also at university. Considering the cases presented above, rhetoric, especially in the light of its practical application, needs more didactic engagement. An effective closing speech will contribute to the factual application of both the functions and the goals of the criminal procedure, thus highlighting a more comprehensive realisation of the principle of material truth (Article $2 \S 2$ of the Polish Code of Criminal Procedure) and the right to defence (Article 6 of the Polish Code of Criminal Procedure).

\section{Literature}

Bafia J., Bednarzak J., Flemming M., Kalinowski S., Kempisty H., Siewierski M., Kodeks postępowania karnego. Komentarz, ed. M. Mazur, Wydawnictwo Prawnicze, Warszawa 1971.

Cieślak M., Polska procedura karna: podstawowe zatożenia teoretyczna, Państwowe Wydawnictwo Naukowe, Warszawa 1971.

Cieślak W., Pawelec K. J., Tuleya I., Kodeks postepowania karnego. Praktyczny komentarz do zmian, Wydawnictwo Difin, Warszawa 2015.

Gardocki L., Prawo karne, Wydawnictwo C. H. Beck, Warszawa 2015.

Gout T., Sztuka wymowy. Technika publicznego przemawiania - częśc I, Spółdzielnia Wydawnicza „Nowa Epoka”, Warszawa 1946.

Gruza E., Psychologia sadowa dla prawników, Wydawnictwo Oficyna a Wolters Kluwer business, Warszawa 2009.

Gierowski J. K., Jaśkiewicz-Obydzińska T., Najda M., Psychologia w postępowaniu karnym, Wydawnictwo LexisNexis, Warszawa 2008.

46 P. K. Sowiński, op. cit., p. 672.

47 Ibidem, p. 672, quotation after: Judgement of the Supreme Court of 11 November 1957, II K 742/57, OSNPG 1958, no. 4, item 19.

48 The following event may serve as an example: http://www.adwokatura.pl/z-zycia-nra/znamyjuz-zwyciezcow-konkursu-krasomowczego-2014/ [access: 10 Jan 2016]. 
306 | Adam Mickiewicz University Law Review

Grzegorczyk T., Tylman J., Polskie postepowanie karne, Wydawnictwo LexisNexis, Warszawa 2005.

Jabłońska-Bonca J., Prawnik a sztuka negocjacji i retoryki, Wydawnictwo Prawnicze LexisNexis, Warszawa 2003.

Jaworski S., Metodyka pracy adwokata i radcy prawnego w sprawach karnych, Wydawnictwo C. H. Beck, Warszawa 2015.

Kalinowski S., Siewierski M., Kodeks postępowania karnego. Komentarz, Wydawnictwo Prawnicze, Warszawa 1966.

J. Kasprzak, Wybraneproblemy metodologiczne badań w zakresie procesu karnego i kryminalistyki, Wybrane problemy procesu karnego i kryminalistyki, ed. J. Kasprzak, B. Młodziejowski, Wydawnictwo Volumina.pl Daniel Krzanowski, Szczecin-Olsztyn 2010.

H. Kempisty, Metodyka pracy sędziego w sprawach karnych, Wydawnictwo Prawnicze, Warszawa 1955.

Dowody i postepowanie dowodowe w procesie karnym. Komentarz praktyczny z orzecznictwem. Wzory pism procesowych, ed. P. Kruszyński, M. Błoński, M. Zbrojewska, , Wydawnictwo C. H. Beck, Warszawa 2015.

Lipczyńska M., Ponikowski R., Maty komentarz do kodeksu postępowania karnego, Państwowe Wydawnictwo Naukowe, Warszawa 1988.

Muras Z., Wyjaśnienia oskarżonego w procesie karnym i prawie karnym materialnym, Wydawnictwo C. H. Beck, Warszawa 2005.

Seremet A., Odpowiedzialnośc prokuratora za niestuszne skazanie, in: Niestuszne skazania-przyczyny i skutki, ed. E. Chojniak, Wydawnictwo C. H. Beck, Warszawa 2017.

Kodeks postępowania karnego. Komentarz, ed. J. Skorupka, ,Wydawnictwo C. H. Beck, Warszawa 2016.

Sowiński P. K., Ostatnie stowo oskarżonego (art. 406 k.p.k.), in: Węztowe problemy procesu karnego, ed. P. Hofmański, Wydawnictwo Oficyna a Wolters Kluwer business, Warszawa 2010.

Stefański R. A., Metodyka pracy prokuratora w sprawach karnych, Wydawnictwo Wolters Kluwer, Warszawa 2017.

Szerer M., Kultura i Prawo, Państwowy Instytut Wydawniczy, Warszawa 1981.

S. Śliwiński, Polski proces karny przed sqdem powszechnym. Zasady ogólne, Państwowe Wydawnictwo Naukowe, Warszawa 1959.

Rzetelny proces karny w orzecznictwie sq̨dów polskich i międzynarodowych, ed. P. Wiliński, Wydawnictwo Oficyna a Wolters Kluwer business, Warszawa 2009.

Z. Ziembiński, Logika praktyczna, Wydawnictwo Naukowe PWN, Warszawa 2002.

Constitution of the Republic of Poland of 2 April 1997, Dz.U. 1997 no. 78, item 483.

European Convention for the Protection of Human Rights and Fundamental Freedoms made in Rome on 4 November 1950, as amended by Protocols Nos. 11 and 14 and supplemented by Protocol no. 2 - OJ.1993.61.284. 
Polish Act of 6 June 1997 - Code of Criminal Procedure - Dz.U.1997, no. 89, item 555, as amended.

Polish Act of 6 June 1997 - Criminal Code (Dz.U. 1997, no. 88, item 553, as amended.

Resolution of the Supreme Court of 11 January 2006 , I KZP 49/05, OSNKW 2006, no. 2 , item 12 ,

Judgement of the Supreme Court of 18 November 1957., II K 742/57, OSNPG 1958, no. 4 , item 19

Judgement of the Supreme Court of 23 July 1975, II KR 62/75, OSNKW 1975, no. 9, item 126

Judgement of the Supreme Court of 18 January 1980, III KR 421/79, Lex no. 17210

Judgement of the Supreme Court of 9 August 2002, V KKN380/00, LEX nr 57167

Judgement of the Court of Appeal in Katowice of 29 March 2001, II Aka 98/01

Judgement of the District Court in Olsztyn VII K 125/12

Judgement of the District Court in Olsztyn VII K 132/12

Judgement of the Regional Court in Olsztyn - II K 149/12

Judgement of the Regional Court in Olsztyn - II K 106/13

Judgement of the Regional Court in Olsztyn II K 156/13

Judgement of the Regional Court in Olsztyn II K 181/13

Judgement of the District Court in Olsztyn: VII K 82/12,

Judgement of the District Court in Olsztyn VII K 85/12

Judgement of the District Court in Olsztyn VII K 88/12

Judgement of the District Court in Olsztyn VII K 95/12

Judgement of the District Court in Olsztyn VII K 96/12

Judgement of the District Court in Olsztyn VII K 107/12

Judgement of the District Court in Olsztyn VII K 109/12

Judgement of the District Court in Olsztyn VII K 125/12

Judgement of the District Court in Olsztyn VII K 132/12

Judgement of the District Court in Olsztyn VII K 144/12

Judgement of the District Court in Olsztyn VII K 145/12

Judgement of the District Court in Olsztyn II K 469/12

\section{SUMMARY}

\section{Closing Speech - Between Theory and Practice}

The development of rhetoric in criminal procedure is reflected in every court trial. The right of the parties to present their final speech before the court (Article 406 of the Polish Code of Criminal Procedure) is important for achieving the required verdict. This 
308 | Adam Mickiewicz University Law Review

paper tries to answer the question about the actual extent to which the said regulation is used by the parties to achieve their objectives. The deliberations are based on an analysis of the results of research conducted by the author.

Keywords: closing speech, criminal procedure, court trial, prosecutor, defence attorney

Marta Kowalczyk-Ludzia, Faculty of Law and Adminitration, The University of Warmia and Mazury in Olsztyn, Warszawa 98, 10-702 Olsztyn, Republic of Poland, e-mail: marta.kowalczyk.ludzia@gmail.com. 